\title{
PENDIDIKAN KARAKTER PEDULI LINGKUNGAN MELALUI PROGRAM ADIWIYATA BERBASIS EKOPEDAGOGIK
}

\author{
Trisni Handayani ${ }^{1}$, Zulela MS ${ }^{2}$, Chrisnaji Banindra Yudha ${ }^{3}$ \\ ${ }^{1}$ Universitas Muhammadiyah Prof. Dr. HAMKA, Indonesia \\ ${ }^{2}$ Universitas Negeri Jakarta, Indonesia \\ ${ }^{3}$ STKIP Kusuma Negara, Indonesia
}

\begin{abstract}
The moral degradation and character of the nation's children are increasingly worrying. This phenomenon can damage the realization of the superior generation of the nation's generation. So it takes a touch in basic education that can provide reinforcement and the formation of student character in sustainably loving the environment. This study aims to determine the effect of the Adiwiyata program on environmental education based on ecopedagogic-based care for high-class students at Cijantung 03 Jakarta Primary School the research method used is a descriptive associative quantitative approach, a simple paradigm research design. The sample used was stratified random sampling with validity testing using Pearson product-moment correlation. While the reliability test uses Alfa Cronbach. Based on the analysis of the data it can be concluded that the results of this study indicate that there is a significant influence in fostering environmental care character for schools that receive the Adiwiyata-based Ecopedagogic program including habits in maintaining the cleanliness and beauty of the school environment that has an impact on students' habits of maintaining, preserving, and discarding orderliness rubbish and recycle the garbage in the environment.
\end{abstract}

Keyword: Character Education, Caring for the Environment, Adiwiyata, Ecopedagogic

\begin{abstract}
Abstrak: Degradasi moral dan karakter anak bangsa semakin mengkhwatirkan. Fenomena ini dapat merusak terwujudnya genarasi penerus bangsa yang unggul. Maka butuh sentuhan dalam pendidikan dasar yang dapat memberikan penguatan dan pembentukan karkater siswa dalam mecintai lingkungan secara berkelanjutan. Penelitian ini bertujuan untuk mengetahui pengaruh program Adiwiyata terhadap pendidikan karkter peduli lingkungan berbasis ekopedagogik pada siswa kelas tinggi Sekolah Dasar Negeri Cijantung 03 Jakarta. Metode penelitian yang digunakan adalah pendekatan kuantitatif asosiatif deskriptif, desain penelitian paradigma sederhana. Sampel yang digunakan adalah statified random sampling dengan uji validitas menggunakan korelasi pearson product moment. Sedangkan uji reliabilitas menggunakan Alfa Cronbach. Berdasarkan analisis data maka dapat disimpulkan hasil penelitian ini menunjukkan bahwa terdapat pengaruh yang signifikan dalam menumbuhkan karkater peduli lingkungan bagi sekolah yang memperoleh penghargaan program Adiwiyata berbasis Ekopedagogik diantaranya kebiasaaan dalam menjaga kebersihan dan keasrian lingkungan sekolah yang berdampak pada kebiasaan siswa menjaga, melestarikan, dan ketertiban membuang sampah dan mendaur ulang sampah di lingkungan.
\end{abstract}

Kata Kunci: Pendidikan Karakter, Peduli Lingkungan, Adiwiyata, Ekopedagogik

\footnotetext{
'Universitas Muhammadiyah Prof. Dr. HAMKA, Email: trisni国uhamka.ac.id

${ }^{2}$ Universitas Negeri لakarta, Email: zulelams回uni.ac.id

${ }^{3}$ STKIP Kusuma Negara, Email: chrisnajiby国stkipkusumanegara.ac.id
} 
PENDAHULUAN

Pendidikan formal merupakan sarana yang efektif dalam pembentukan karakter (Kemendikbud, 2017). Siswa dapat mempunyai kebiasaan yang positif secara intensif dapat dilakukan melalui sekolah. Pendidikan merupakan tempat yang diunggulkan untuk pembentukan karakter dalam menghadapi tantangan global (Rokhman, Hum, Syaifudin, \& Yuliati, 2014). Pembentukan karakter sangatlah penting dimulai dari sedini mungkin dengan dukungan dan motivasi keluarga. Pada dasarnya pendidikan karakter bukanlah hal yang baru sebagaimana terlihat jelas nilai yang tertuang pada Pancasila sebagai dasar Negara (Murniyetti, Engkizar, \& Anwar, 2016). Begitu juga dinegara lain prioritas utama dalam pendidikan adalah karakter peserta didik yang dimulai sejak dini seperti contohnya di negara Taiwan dan Jepang yang unggul dengan karakternya (Mei-Ju, Chen-Hsin, \& Pin-Chen, 2014), (Junaedi Mahfud, 2017). Banyak orang cerdas namun gagal dalam hidupnya hal ini disebabkan karena tidak mempunyai karakter. Karakter adalah watak, tabiat, akhlak, atau juga kepribadian seseorang yang terbentuk dari hasil internalisasi berbagai kebajikan yang diyakini dan mendasari cara pandang, berfikir, sikap, dan cara bertindak orang tersebut, kebajikan tersebut terdiri atas sejumlah nilai, moral, dan norma seperti jujur, berani bertindak, dapat dipercaya, hormat kepada orang lain (Hendarman \& Dkk, 2017). Pendidikan karakter bertujuan untuk meingkatkan mutu proses dan hasil pendidikan yang mengarah pada pembentukan karakter dan akhlak mulia siswa secara utuh, terpadu, dan seimbang, sesuai dengan standar kompetensi lulusan pada setiap satuan pendidikan (Yuliana, Dahlan, \& Fahri, 2020). Pembentukan karakter harus dilakukan dengan pembiasaan (Hidayat Nur, 2016). Kakater yang terbentuk tidaklah instan butuh proses dan pemodelan.
Salah satu karakter yang berdampak besar yaitu peduli lingkungan. Masalah lingkungan sampai saat ini masih menjadi polemik yang membuat resah sehingga menimbulkan masalah bagi bumi kita dan membutuhkan penyelesaian segera. Masalah lingkungan hidup bukanlah masalah baru melainkan sama dengan usia bumi ini, yang menurut para ahli usianya sekitar lima milyar tahun (Al-anwari, 2014). Kehidupan modern di era teknologi banyak kegiatan yang mengeksploitasi alam dengan intensitas yang tinggi, berimbas pada kerusakan lingkungan yang bertambah luas, oleh karena itu pembentukan mindset peduli lingkungan perlu dilakukan sejak dini dengan berupaya mencegah kerusakan lingkungan alam sekitar dan mengembangkan upaya untuk memperbaiki kerusakan yang telah terjadi (Widyaningrum, 2016), (Susilawati Fitriah, Gunarhadi \& Maret, 2020). Ada beberapa hal yang dapat mempengeruhi karakter peduli lingkugan berupa media pembelajaran yang digunakan guru pada saat proses belajar mengajar berlangsung dengan pendekatan scince-edutainmet (F. Fatkhriyah, 2014). Guru ketika mengajar hendaknya memperhatikan tema yang sedang diajarkan karena akan berkorelasi dengan pembentukan karakter peduli lingkungan (Ariyani \& Wangid, 2016). Hasil penelitian lain mengungkapkan bahwa pembentukan karakter peduli lingkungan dapat dibentuk melalui efektifitas model Experiental Jelajah Alam Sekitar (EJAS) dengan pendekatan science edutainment, menunjukan hasil $73 \%$ peningktan peduli lingkungan dengan kategori tinggi, dan dapat meningkatkan perilaku tanggung jawab sebesar $65 \%$ dengan kategori sedang (Savitri Wanabuliandari dan Susilo Rahardjo, 2017). Kepedulian lingkungan sangat erat didukung oleh kebijakan sekolah, pelaksanaan kurikulum, kegiatan lingkungan partisipatif dan pengelolaan sarana pendukung ramah lingkungan (Rokhmani, 2016). 
Ekologi mengambil peran penting dalam abad ini. Melihat fenomena kerusakan lingkungan yang banyak disebabkan oleh tangan-tangan manusia yang tidak bertanggung jawab yang mengakibatkan Bumi menjadi marah. Maka butuh pendidikan lingkungan yang disampaikan dalam proses pembelajaran. Ekopedagogik merupakan pendidikan lingkungan yang dapat membawa perubahan kesadaran pada siswa sekolah dasar untuk melakukan ekoliterasi. Ekopedagogik adalah sebuah pendekatan untuk membangun kesadaran literasi ekologi, literasi budaya, dan literasi teknologi yang menekankan pada pendekatan cinta kasih, partisipasi dan kreatifitas masyarakat dalam menciptakan masyarakat baru berkelanjutan (Puspawati Ayu Dewa, 2018). Pendidikan berbasis ekopedagogik dapat membangun kesadaran kritis dan mengembangkan karakter peserta didik untuk memahami hakikatnya sebagai manusia yang memiliki relasi dengan alam dan memanifestasikan kesadaran tersebut melalui perilaku bijak terhadap alam (Irianto, Yunansah, Herlambang, \& Mulyati, 2020). Ekopedagogik harus masuk kedalam kurikulum muatan lokal dengan menerapkan sekolah berbudaya peduli lingkungan mewujudkan warga sekolah yang tertanggung jawab dalam kegiatan perlindungan, pelestarian, dan pencegahan perusakan lingkungan dan sumber daya alam lewat tata kelola sekolah yang baik untuk mendukung pembangunan berkelanjutan (Hidayanti, Abidin, \& Susilaningsih, 2018), (Kementrian Lingkungan Hidup dan Kemendikbud, 2011). Pendidikan berbasis ekopedagogik merupakan suatu pendekatan yang berorientasi pada upaya pengembangan multidomain siswa secara bermakna, artinya bahwa pembelajaran tidaklah dikembangkan berdasarkan pada orientasi pencapaian domain kognitif semata, melainkan harus mencangkup multidomain yang meliputi kognitif, afektif, dan psikomotorik pada prinsip pembelajaran yang menekankan pada pendekatan kontekstual artinya pembelajaran secara esensial dikembangkan dengan menggunakan sumber dan media yang berada dalam konteks kehidupan peserta didik, agar peserta didik mampu mengontruksi pengetahuan secara bermakna (Yunansah \& Herlambang, 2017). Bukanlah hanya strategi guru saja yang dapat dijadikan acuan dalam pemebntukan karakter peduli lingkungan, butuh suatu majemen sekolah yang baik di dukung dengan program pemerintah agar dapat mejadi dasar rujukan berkelanjutan.

$$
\text { Kerjasama kementerian }
$$

Lingkungan Hidup dengan Kementerian Pendidikan dan Kebudayaan membuat suatu program Adiwiyata untuk jenjang sekolah formal. Adiwiyata mempunyai makna sebagai tempat yang baik dan ideal dimana dapat diperoleh segala ilmu pengetahuan dan berbagai norma serta etika yang dapat menjadi dasar manusia menuju terciptanya kesejahteraan hidup kita dan menuju kepada cita-cita pembangunan berkelanjutan (Kementrian Lingkungan Hidup dan Kemendikbud, 2011). Sekolah merupakan lembaga yang berperan untuk mewujudkan generasi penerus peduli pada lingkungan. Sekolah wajib memberikan tolak ukur bagi terciptanya lingkungan hidup yang bersih dan sehat. Semua warga sekolah wajib menciptakan dan menjaga lingkunga sekolah dan sekitarya. Salah satu contoh Sekolah Dasar Negeri Cijantung 03 Jakarta Timur, yang telah mendapat penghargaan sekolah Adiwiyata. Oleh karena itu sudah selayaknya peserta didik yang ada di SDN tersebut telah menerapkan pendidikan karakter peduli lingkungan. Adiwiyata adalah sekolah yang mampu mebimbing siswa dan Seluruh Warga sekolah dalam upaya Pemanfaatan, pengelolaan dan pelestarian lingkungan dengan baik, lingkungan yang sehat, hijau dan bersih. SDN Cijantung 03 Jakarta Timur telah mendapatkan Adiwiyata Mandiri. Namun, tetap saja dalam pelaksanaannya masih terdapat kendala ada siswa yang masih belum memiliki karakter peduli lingkungan, meskipun telah 
diterapkan dan sekolah telah mendapatkan penghargaan Adiwiyata. Tujuan dari penelitian ini adalah untuk mengatahui seberapa besar pengaruh program Adiwiyata terhadap pembentukan karatakter peduli lingkungan berbasis ekopedagogik pada siswa kelas tinggi.

\section{METODOLOGI PENELITIAN}

Penelitian ini mengunakana pendekatan kunatitatif asosiatif. Dengan desain penelitian paradigma sederhana. Karakteristik subjek penelitian yaitu siswa sekolah dasar SDN Cijantung 03 Jakarta Timur. Populasinya berjumlah 279 siswa, sampel berjumlah 160 yang didapatkan dengan menggunakan teknik Proporionate stratified sampling menggunakan rumus Isaac dan Michael pada taraf 5\% kesalahan. Teknik pengumpulan data dan analisis data dengan melakukan uji normalitas dan homogenitas. Kemudian, dilakukan pengujian hipotesis dengan menggunakan teknik korelasi yaitu korelasi Pearson Product Moment. Dalam uji signifikansi korelasi product moment, jika r hitung lebih kecil dari $r$ tabel maka Ho diterima dan $\mathrm{Ha}$ ditolak, namun jika r hitung lebih besar dari $r$ tabel maka Ha diterima.

\section{HASIL PENELITIAN DAN PEMBAHASAN}

Pendidikan karakter peduli lingkungan diterapkan sesuai dengan visi, misi dan tujuan Sekolah Dasar Negeri 03 Cijantung Jarkarta. Sekolah tersebut telah menamkan dengan berbagai metode diantaranya yaitu, pemodelan yang dilakukan oleh para guru, pembiasaan yang setiap harinya dilakukan mulai dari awal sampai akhir pembelajaran. Dapat terlihat pada gambar 1 .

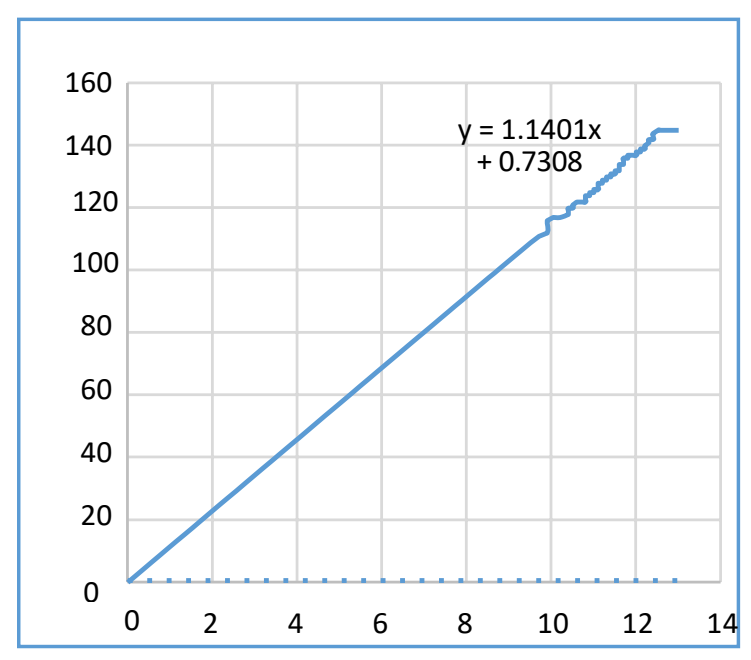

Gambar 1. Grafik Persamaan Linieritas karkter Peduli Lingkungan melalui Adiwiyata berbasis Ekopedagogik

Berdasarkan gambar 1 dapat telihat bahwa kurva menghasilkan bentuk yang linier dimana setiap nilai $X$ akan mempengaruhi peningkatan nilai $Y$. selanajutnya peneliti melakukan uji hipotesis dan menunjukan Ho ditolak sehingga dapat maka dapat dikatakan bahwa terdapat pengaruh yang positif dan signifikan Pembentukan karakter peduli lingkungan terhadap program Adiwiyata berbasis Ekopedagogik yakni sebesar 97,05\%. Lebih lanjut dapat dilihat pada tabel 1.

Tabel 1. Pengujian Signifikansi Variabel

\begin{tabular}{llll}
\hline Variabel & Koefisien & Determinasi & UL \\
\hline X dan Y & 0,98 & $97,05 \%$ & 2,756 \\
\hline
\end{tabular}

Dari perhitungan pengujian signifikansi dibuatlah tabel distribusi kecenderungan variavel Program Adiwiyata sebagai berikut:

Tabel 2. Distribusi Kecenderungan Variabel

\begin{tabular}{ccll}
\hline Skor & Frekuensi & $\%$ & Kategori \\
\hline$\geq 113$ & 100 & $62,5 \%$ & Tinggi \\
$107-113$ & 44 & $27,5 \%$ & Sedang \\
$<107$ & 16 & $10 \%$ & Kurang \\
\hline 160 & $100 \%$ & & \\
\hline
\end{tabular}

Maka dapat dikatakan bahwa kecenderungan siswa kelas tinggi SDN Cijantung 03 Jakarta pada penguatan 
pendidikan karakter peduli lingkungan terhadap program Adiwiyata berbasis Ekopedagogik dikategorikan tinggi. Karakter peduli lingkungan secara umum sudah berjalan sangat baik. Hal ini dapat dilihat dari perubahan sikap peduli lingkungan yang diperlihatkan siswa dari kehidupan sehari-hari di sekolah dan lingkungan rumah. Peningkatan tersebut disebakan adanya program sekolah yang berdasarkan pada ekopedagogik sehingga membawa sekolah ini mendapatkan penghargaan Adiwiyata Mandiri. Perencanaan pendidikan karakter memang harus bersumber dari manajemen sekolah (Sukendar, Usman, \& Jabar, 2019) yang dapat dilakuakn dengan pembiasaan. Pembiasaan yang dilakukan siswa sesuai dengan motto mereka yaitu LISA (Lihat Sampah Ambil). Siswa secara sadar memungut sampah kemudian membuangnya sesuai denga kategori sampah tersebut. Setiap hari siswa berpartisipasi aktif menjalakan tugas piket kelas dan sekolah secara bergantian, yang dibimbing oleh guru. Mulai dari bercocok tanam di belakang sekolah, beternak ikan, dengan cara memupuk, merawat, sampai akhirnya siswa dapat memanen hasil yang telah mereka lakukan dengan peduli, menjaga, merawat dan rasa memiliki lingkungan. Sejalan dengan hasil penelitian yang dilakukan oleh Rachma bahwa ekopedagogik bukan hanya mempelajari ligkungan manusia saja, tetapi lebih luas lagi diperkenalkan pada lingkungan sekitar baik dengan tumbuhan maupun dengan hewan, Karena pada hakekatnya manusia adalah mahkluk sosial yang hidup berdampingan baik dengan sesama manusia dengan alam sekitar, dan berinteraksi dengan hewan-hewan disekitar (Rachmadyanti, 2017). SDN Cijantung 03 telah mempunyai ladang untuk berkebun dan bercocok tanam baik itu tanaman obat maupun tanaman yang biasa di konsumsi. Selain itu sekolah juga mempunyai kolam yang dibudidayakan untuk ternak ikan yang dirawat mulia dari bibit ikan. Semua siswa diminta untuk berpartisipasi aktif dengan harapan dapat diterapkan dilingkungan rumah masing-masing. Sekolah juga sudah tidak lagi menggunakan plastik atau steorofom. Semua siswa diwajibkan untuk membawa tempat minum dan tempat makan masing-masing. Hal ini sangat efektif mengurangi intensitas sampah yang ada disekolah sehingga kantin bersih dan sehat dapat tercipta dengan baik. Program Adiwiyata memberikan dampak yang positif terhadap pembentukan karkater peduli lingkungan kepada siswa dan seluruh masyarakat sekolah. Sejalan dengan hasil penelitian (Siswanto, Karimullah, Prasetyawati, \& Nurhayati, 2019) proses pembelajaran disekolah dirumuskan berdasarkan aspek Adiwiyata dan educotourism dengan prinsip partisipatif dan berkelanjutan. Pembiasaan ini berpengaruh pada perilaku siswa di lingkungan rumah dan lingkungan masyarakat. Karna memang pembentukan karakter tidak dapat berjalan sendiri tanpa dukungan dari sekolah, orang tua dan masyarakat. Pembiasaan ini tidaklah terputus harus bersinergi dan berkelanjutan sehingga terbentuklah karakter yang kuat.

\section{KESIMPULAN}

Berdasarkan hasil pembahasan penelitian maka dapat disimpulkan bahwa program Adiwiyata berpengaruh posistif terhadap pembentukan karakter peduli lingkungan yang diperkuat dengan ekopedagogik melalui proses pembelajaran kontekstual. Pendidikan lingkungan bukan hanya sekedar gambaran teori yang diberikan kepada siswa namun lebih kongkrit dengan cara berbuat, bertindak, melakukan langsung dengan keadaan yang sesungguhnya. Hal ini terbukti dengan adanya peningkatan kesadaran siswa terhadap kebersihan lingkungan sekitarnya yang sesuai dengan indikator karakter peduli lingkungan antara lain peduli pada kesehatan dan kebersihan lingkungan, Peduli terhadap usaha hemat energi, peduli pada penanggulangan dan pengelolaan sampah, serta peduli terhadap tanaman, tumbuh-tumbuhan dan mahluk hidup 
lainnya. Melalui program Adiwiyata, sekolah terbantu untuk mempermudah dalam proses penciptaan karakter peduli lingkungan pada peserta didik di sekolah dasar.

\section{DAFTAR PUSTAKA}

Al-anwari, A. M. (2014). Strategi Pembentukan Karakter Peduli Lingkungan Di Sekolah Adiwiyata Mandiri. Ta'dib, 19(02), 227-252.

Ariyani, Y. D., \& Wangid, M. N. (2016). Pengembangan Bahan Ajar TematikIntegratif Berbasis Nilai Karakter Peduli Lingkungan Dan Tanggung Jawab. Jurnal Pendidikan Karakter, (1), 116-129. https://doi.org/10.21831/jpk.v0i1.107 37

F. Fatkhriyah. (2014). Pengembangan Media Pembelajaran IPA Terpadu Berkarakter Peduli Lingkungan Tema Konservasi Berpendekatan ScienceEdutainment. Jurnal Pendidikan IPA Indonesia, 3(1), 140-145. Retrieved from

http://journal.unnes.ac.id/nju/index.ph p/jpii

Hendarman, \& Dkk. (2017). Konsep dan Pedoman Penguatan Pendidikan Karakter. Pusat Analisis Dan Sinkronosasi Kebijakan Sekretariat Jenderal Kementrian Pendidikan Dan Kebudayaan, 1-64. Retrieved from http://file.upi.edu/Direktori/FIP/jurnal _psikologi_pend_dan_bimbingan/195 003211974121-

Sunaryo_Kartadinata/Konsep dan Pedoman PPK Cetakan Kedua.pdf

Hidayanti, N., Abidin, Z., \& Susilaningsih, S. (2018). Implementasi Pendidikan Lingkungan Hidup Sebagai Kurikulum Muatan Lokal Ekopedagogi Dalam Membangun Karakter Siswa Di SDN Lowokwaru 2 Malang. JINOTEP (Jurnal Inovasi Dan Teknologi Pembelajaran) Kajian Dan Riset Dalam Teknologi Pembelajaran, 4 (2), 106-112. https://doi.org/10.17977/um031v4i22
018 p106

Hidayat Nur. (2016). Implementasi Pendidikan Karakter Melalui Pembiasaan Di Pondok Pesantren Pabelan. JPSD, 2 No 1(1), 128-145. https://doi.org/10.1192/bjp.111.479.1 009-a

Irianto, D. M., Yunansah, H., Herlambang, Y. T., \& Mulyati, T. (2020). Meningkatkan Kecerdasan Ekologis Melalui Model Multiliterasi Berbasis Ecopedagogy Approach. EduHumaniora | Jurnal Pendidikan Dasar Kampus Cibiru, 12(1), 81-90. https://doi.org/10.17509/eh.v12i1.188 20

Junaedi Mahfud, S. F. (Walisongo S. I. U. (2017). Moral Education in Japanese Schools A Model for Improving Character Education in Indonesia. Analisa Journal of Social Science and Religion, 2(1), 23-40. https://doi.org/http://dx.doi.org/10.18 784/analisa.v2i01.416

Kemendikbud. (2017). Gerakan Penguatan Pendidikan Karakter (PPK) [Infographics of the Strengthening Character Education Movement]. Indonesian Ministry of Education and Culture, 1-10. Retrieved from https://cerdasberkarakter.kemdikbud. go.id/?page_id=132

Kementrian Lingkungan Hidup dan Kemendikbud. (2011). Buku Panduan Adiwiyata. Adiwiyata.

Mei-Ju, C., Chen-Hsin, Y., \& Pin-Chen, H. (2014). The Beauty of Character Education on Preschool Children's Parent-child Relationship. Procedia Social and Behavioral Sciences, 143, 527-533.

https://doi.org/10.1016/j.sbspro.2014. 07.431

Murniyetti, M., Engkizar, E., \& Anwar, F. (2016). Pola Pelaksanaan Pendidikan Karakter Terhadap Siswa Sekolah Dasar. Jurnal Pendidikan Karakter, 6(2), 156-166. https://doi.org/10.21831/jpk.v6i2.120 45 
Puspawati Ayu Dewa, S. K. P. S. (Universitas M. D. (2018). Ekopedagogi Berbasis Lanskap Budaya Subak: Sumber Belajar Alternatif dalam Menunjang Ekowisata dan Pengelolaan Lingkungan. Prosiding Seminar Nasional Pendidikan Biologi, 186190.

Rachmadyanti, P. (2017). Penguatan Pendidikan Karakter Bagi Siswa Sekolah Dasar Melalui Kearifan Lokal. JPSD Vol.3 No.2, 3(2), 201214.

Rokhman, F., Hum, M., Syaifudin, A., \& Yuliati. (2014). Character Education for Golden Generation 2045 (National Character Building for Indonesian Golden Years). Procedia - Social and Behavioral Sciences, 141, 1161-1165. https://doi.org/10.1016/j.sbspro.2014. 05.197

Rokhmani, T. A. (2016). Implementasi Pendidikan Karakter Peduli Lingkungan. Jurnal Pendidikan Guru Sekolah Dasar, 5(3), 295-306.

Savitri Wanabuliandari dan Susilo Rahardjo, S. (2017). Peningkatan Perilaku Peduli Lingkungan Dan Tanggung Jawab Siswa Melalui Model Ejas Dengan Pendekatan Science Edutainment. Jurnal Pendas, 4(1), 1-7.

Siswanto, Karimullah, Prasetyawati, R., \& Nurhayati. (2019). Environmental cultured education and its implication on the student's competencies in an adiwiyata school. Cakrawala Pendidikan, 38(3), 552-564. https://doi.org/10.21831/cp.v38i3.231 54

Sukendar, A., Usman, H., \& Jabar, C. S. A. (2019). Teaching-loving-caring (asahasih-asuh) and semi-military education on character education management. Cakrawala Pendidikan, $38(2)$, 292-304. https://doi.org/10.21831/cp.v38i2.244 52
Susilawati Fitriah, Gunarhadi, H., \& Maret, U. S. (2020). Pentingnya Pengembangan Bahan Ajar Tematik dalam Meningkatkan Karakter Peduli Lingkungan Siswa. EduHumaniora | Jurnal Pendidikan Dasar Kampus Cibiru, 12(1), 62-68. Retrieved from https://ejournal.upi.edu/index.php/edu humaniora/article/view/15068/pdf

Widyaningrum, R. (2016). Pembentukan Karakter Peduli Lingkungan Siswa Sekolah Dasar Melalui Sekolah Peduli dan Berbudaya Lingkungan. Widya Wacana, 11(1), 108-115.

Yuliana, N., Dahlan, M. R., \& Fahri, M. (2020). Model Pendidikan Holistik Berbasis Karakter Di Sekolah Karakter Indonesia Heritage Foundation. EduHumaniora| Jurnal Pendidikan Dasar Kampus Cibiru, 12 (1), 15-24. https://doi.org/10.17509/eh.v12i1.158 72

Yunansah, H., \& Herlambang, Y. T. (2017). Pendidikan Berbasis Ekopedagogik Dalam Menumbuhkan Kesadaran Ekologis Dan Mengembangkan Karakter Siswa Sekolah Dasar. EduHumaniora | Jurnal Pendidikan Dasar Kampus $\begin{array}{lll}\text { Cibiru, } & 9 & \text { (1), }\end{array}$ https://doi.org/10.17509/eh.v9i1.6153 